\title{
Democracy and Growth Nexus in Indonesia
}

\begin{tabular}{|c|}
\hline Azwar Iskandar, Achmat Subekan \\
Financial Education and Training Agency of Makassar \\
Ministry of Finance of Indonesia \\
Corresponding Author: azwar.iskandar@gmail.com \\
\hline
\end{tabular}

Recieved: January 2019 | Revised: May 2019 | Accepted: August 2019

\begin{abstract}
The objective of this study is to analyze the causality between democracy and economic growth in Indonesia for the period of 1995 to 2017. This study performs a multivariate cointegration test and cross-check this long-run relationship with an autoregressive distributed lag (ARDL) model approach to cointegration. This study also use the Granger causality test within a vector error correction model (VECM) framework and estimate three different models using a non-linear specification: Ordinary Least Squares (OLS), Fully Modified OLS (FM-OLS) and Dynamic Ordinary Least Squares (DOLS). The results show cointegration among the variables specified in the model when political stability is taken into account. Indeed, for economic growth and democracy to move together in the long run, they need to be associated with political stability. The tests for Granger causality conducted show a long-run causality running from GDP and political stability to democracy. In other word, the economic growth and political stability Granger cause democracy. It is the economic performance that influences democracy and not the reverse. In short-run, there is neutrality causation between democracy and growth, democracy and political stability, growth and political stability. These results suggest that economic growth through strong institutions is a precondition for democratization.
\end{abstract}

Keywords: democracy, growth, political stability, ARDL, Granger

JEL Classification: H80; P48; K16

How to Cite: Iskandar, A., \& Subekan, A. (2019). Democracy and Growth Nexus in Indonesia. Jurnal Ekonomi Pembangunan: Kajian Masalah Ekonomi dan Pembangunan, 20(2). 208-221. doi:https://doi. org/10.23917/jep.v20i2.7581

DOI: https://doi.org/10.23917/jep.v20i2.7581

\section{Introduction}

There has been a surge of interest in the relationship between democracy and economic growth in recent years. This interest reflects, at least partly, that the relationship between democracy and economic growth is contentious. While some studies have found that democracy has a positive effect on economic growth, other studies suggest a negative relationship or no relationship at all. Similarly, althoughmost studies have found that economic growth has a positive effect on democracy, there is no consensus on this issue, particularly at lowlevels of economic development.Tavares and Wacziarg (2001) find that democracy fosters growth by improving the accumulation of human capital and by lowering income inequality, but hinders growth by reducing the rate of physical accumulation and by raising the ratio of government consumption to GDP. They find that the net effect of democracy on growth is moderately negative. Acemoglu, Naidu, Restrepo, and Robinson (2014) provide evidence that democracy has a significant and robust positive effect on GDP. Their results 
Jurnal Ekonomi Pembangunan: Kajian Masalah Ekonomi dan Pembangunan, 20 (2), 2019, 208-221

suggest that democracy increases future GDP by encouraging investment,increasing schooling, inducing economic reforms, improving public good provision, and reducingsocial unrest. They find little support for the view that democracy is a constraint on economicgrowth for less developed economies.Narayan, Narayan, \& Smyth (2011) examined the relationship between democracy and economic growth in 30 Sub-Saharan African countries found that -in the long run- real GDP Granger causes democracy and an increase in GDP results in an improvement in democracy - in Botswana and Niger with both datasets, for Chad with the Freedom House data only and for Cote d'Ivoire and Gabon with the LIEC data only.

This paper considers the democracy-growth nexus in Indonesia. With a population of more than 260 million and an economy that ranks tenth in the world in 2014, Indonesia appears destined to be one of the major international players of the 21st century. Since the 1998 overthrow of Suharto's dictatorship, the country has cut its poverty rate in half, and its per capita gross domestic product now exceeds $\$ 3,500$. And despite the weight of decades of dictatorial rule, post-Suharto Indonesia has made steady progress toward becoming a full and functioning democracy. Still, the country faces many of the same challenges today that it faced 20 years ago. An entrenched elite who benefited from years of association with the Suharto regime, including those with ties to the powerful Indonesian military, remains in place. Despite the sharp reduction in poverty, half the population is economically vulnerable and, according to the World Bank, the wealth gap is growing. Uneven health and educational services, and the activity of radical sectarian elements create additional social pressures. Several studies have considered the effect of political variables on economic growth(AzmanSaini, Baharumshah, \& Law, 2010; Cuciniello, 2009)output and government size by reexamining the time inconsistency of optimal monetary and fiscal policies in a general equilibrium model with staggered timing structure for the acquisition of nominal money à la Neiss (Neiss \& Katharine, 1999). Political instability, in particular, has been found to be an important reason for the countries from the Middle East and North Africa (MENA) region (Zouhaier, 2012). However, a problem with most existing studies that have tested for a correlation between democracy and economic growth, including those on the democracy-growth relationship, is that they fail to adequately address the issue of causation. And this limitation of previous research is important given that the causation relation is in dispute. So, this study fills this gap in the literature by contributing to the understanding of the causality between democracy and economic growth especially at low levels of economic development like Indonesia which the study of that in Indonesia context is still very rare found.

The objective of this study is to analyze the causality between democracy and economic growth. More specifically, this paper also attends to investigate the existence of a longrun relationship between them. To this end, this study first performed a multivariate cointegration test with political stability as a control variable on the country dataset running from 1995 to 2017 and cross-check this long-run relationship with an autoregressive distributed lag (ARDL) model approach to cointegration. Next, this study applied the Granger causality test within a vector error correction model (VECM) and estimate three different models using a non-linear specification: Ordinary Least Squares (OLS) estimation, Fully Modified OLS (FM-OLS) and Dynamic Ordinary Least Squares (DOLS). The findings of this study will be necessary to be able to get a clear picture of the extent of the problem of democracy and economic growth in Indonesia and shall analyze and determine the connection or contribution of democracy to the problem of increasing or decreasing the economic condition in Indonesia. The findings shall also be useful to policy makers and the general public not only for the purpose of creating awareness of the adverse effects of democracy and economic growth but 
also to utilise the data in policy formulation and implementation.

The remainder of the paper is set out as follows. The next section provides an overview of the competing hypotheses in the existing literature on the relationship democracy and economic growth. Section 3 sets out the econometric approach. Section 4 summarizes the results and findings. Section 5 contains the conclusion.

\section{Literature Review}

The statistical association between income and democracy is widely investigatedby political economy scholars. Many studies have reported a positive associationbetween income per capita and the degree of democracy supporting the modernization theory according to which thelevel of economic development drives theimplementation and consolidation of democracy (Heid, Working, No, \& Langer, 2011; Benhabib, Corvalan, \& Spiegel, 2013; Rachdi \& Saidi, 2015). Indeed, as the gross domesticproduct (GDP) per capita increases poor countries are more prone to change theirinstitutions argued that citizens ofwealthier countries, who generally have high levels of human capital and income, aremore effective at creating and sustaining democratic institutions. These hypotheses arerelated to the exogenous and endogenous theory of democracy.

There are three major theses concerning the effects of democracy on growth that have been dubbed the "conflict", the "compatibility" and the "skeptical" hypotheses(Narayan et al., 2011). The conflict hypothesis proposes that democracy and economic growth are incompatible. One reason suggested for this incompatibility is that elected officialswillmake myopic decisions designed to maximize their electoral success. This behavior makes officials vulnerable to the overtures of rentseeking interest groups and special interest politics, such as the labour unions whose demands will cut into entrepreneurs' profits and slowthe rate of economic growth. In contrast, the conflict hypothesis proposes that authoritarian regimes are insulated from redistributive politics, which allows them to enact policies conducive to longtermgrowth.Moreover, as the residual claimants of their countries' wealth, dictators have an interest in furthering growth to increase their share of national income.

The compatibility hypothesis provides the opposite view to the conflict hypothesis. First, it suggests that political pluralism and institutional checks and balances are necessary to protect against systemic abuse or predatory behaviour,which are often associatedwith authoritarian regimes. Second, in contrast with the argument made for the conflict hypothesis, it is suggested that democratization might limit rent seeking due to its system of checks and balances (Haan \& Sturm, 2003). This view builds on Rodrik's (1998)and the domestic institutions of conflict-management on the other. Econometric evidence provides support for this hypothesis. Countries that experienced the sharpest drops in growth after 1975 were those with divided societies (as measured by indicators of inequality, ethnic fragmentation, and the likeargument that democratic institutions can be viewed as the ultimate institutions for conflict management as they allow for differences among social groups to be resolved in a predictable, inclusive and participatory manner.

The intermediate position is the skeptical hypothesiswhich proffers that there is no systematic relationship between democracy and economic growth. What really matters is the effectiveness of policies implemented and the stability of the regime, rather than its type (Comeau, 2003). Clague, Keefer, Knack, \& Olson (1996)suggested that there can be growth enhancing democracies and growth-enhancing dictatorships and that the quality of economic policies depends on the time horizon of the dictator in autocracies and whether the democratic systemis durable in democracies. Their empirical findings suggest that autocrats who have been in power for some time provide better contractual and property rights than autocrats who have been in power a shorter period. 
Advocates of the skeptical hypothesis argue that while it might generally be true that there is more economic freedom under a democracy than under authoritarianism, there is no guarantee that there will be an optimal outcome (Esposto \& Zaleski, 1999). Democracies contain those whose aim is to challenge the private property status quo where it is in their best interests.

\section{Research Method}

\subsection{Data and Variables}

This study use data on real Gross Domestic Product (GDP) and democracy for Indonesia in the period of 1995-2017. The study has converted the GDP and democracydata series into Ln for consistent and reliable results. The log-linear specification provides better results because the conversion of the series into logarithm reduces the sharpness in time series data (Ur Rehman \& Shahbaz, 2014). The study use annual frequency data from the Economist Intelligence Unit (EIU), The Global Economy and World Bank's World Development Indicators (WDI). Descriptive statistics of the three variables used, GDP, DEM and POL, variables are presented in Table A1 in the appendix.

According to The Global Economy, political stability index (-2.5 weak; 2.5 strong) is the index of political stability and absence of violence/ terrorism measures perceptions of the likelihood that the government will be destabilized or overthrown by unconstitutional or violent means, including politically-motivated violence and terrorism. The index is an average of several other indexes from the economist intelligence unit, the world economic forum, and the political risk services, among others.

The EIU's index of democracy, on a 0 to 10 scale, is based on the ratings for 60 indicators, grouped into five categories: electoral process and pluralism; civil liberties; the functioning of government; political participation; and political culture. Each category has a rating on a 0 to 10 scale, and the overall Index is the simple average of the five category indexes. The category indexes are based on the sum of the indicator scores in the category, converted to a 0 to 10 scale. Adjustments to the category scores are made if countries do not score a 1 in the following critical areas for democracy: 1. Whether national elections are free and fair; 2 . The security of voters; 3 . The influence of foreign powers on government; and 4. The capability of the civil service to implement policies. If the scores for the first three questions are 0 (or 0.5 ), one point (0.5 point) is deducted from the index in the relevant category (either the electoral process and pluralism or the functioning of government). If the score for 4 is 0 , one point is deducted from the functioning of government category index. The index values are used to place countries within one of four types of regime: 1. Full democracies: scores greater than $8 ; 2$. Flawed democracies: scores greater than 6 , and less than or equal to 8; 3. Hybrid regimes: scores greater than 4 , and less than or equal to 6 ; and 4 . Authoritarian regimes: scores less than or equal to 4 .

\subsection{Unit Root Test}

This study first tested the unit root of all the variables using both the Augmented DickeyFuller (ADF) and Phillips-Perron (PP) tests. After checking for the unit root, this study can then employ either the Johansen and Juselius (1990) or the Engle Granger cointegration test if the series of each variable is integrated of the same order. If the researcher finds that the variables used in this study are not all integrated of the same order and hence, the researcher will employ the ARDL approach to test for cointegration as Johansen method for testing for cointegration requires the variables to be integrated of the same order. Otherwise the predictive power of the models tested would be affected.

\subsection{Cointegration Test}

After determining the order of integration, the concept of cointegration is used toexamine the existence of a cointegrating relationship among the variables. Series that arecointegrated move together in the long run at the same rate, that is to say they obey inequilibrium relationship in the 
long run. Thus, cointegration analysis will tell us whetherthe economic performance is possible with or without democracy. Cointegration can beinvestigated using a multivariate approach proposed by Johansen and Juselius (1990) or the ARDL bounds test. This study cross-checks the cointegration by bothapproaches.

The ARDL approach as developed by Pesaran, Smith, and Shin (2001) overcome these problems as ARDL can be applied irrespective of whether the variables are $\mathrm{I}(0)$ and/or $\mathrm{I}(1)$. More importantly, Johansen approach is not suitable for studying cointegration for small sample time series as in this study. ARDL on the other hand provides robust results even in small samples and this is advantageous as data is only available for annual data and the period available are also limited for many emerging economies like Indonesia. Another benefit of ARDL is that it allows the optimal lag lengths for the variables to differ, while the Johansen approach requires that all variables in the model to have the same number of lags. For this study, AIC (Akaike Information Criterion) has been used to determine the optimal lag lengths for the ARDL model. Eventhough using Schwarz Bayesian Criterion (SBC) provided smaller standard errors for some of our models tested under the ARDL, the researcher found that in some models, SBC ran the models with ARDL $(0,0,0,0)$ such that no ECM statistical output was produced. This is due to the SBC's method of choosing the minimum lag possible and accordingly, the researcher finds that AIC is more suitable for our study.

The first step in ARDL is to empirically investigate the existence of long run relationship between the variables. The calculated F-statistic is then compared against the upper and lower critical bound provided by Pesaran, J. Smith, \& Shin (2001)which correspond to the assumptions that the variables are $\mathrm{I}(0)$ and $\mathrm{I}(1)$ respectively. If the calculated F-statistics exceeds the upper critical bound (UCB), then the series are cointegrated; if it is below the lower critical bound (LCB), there is no cointegration. If the calculated F-statistics is between the UCB and the LCB, then decision about cointegration is inconclusive and knowledge of the cointegration rank of the forcing variables is required to continue further.

The ARDL cointegration test is testing the following hypotheses:

$\mathbf{H}_{\mathbf{0}}: \delta 1=\delta 2=\delta 3=\delta 4=0$ i.e there is no long run relationship between the variables,

$\mathbf{H}_{\mathbf{a}}: \delta 1 \neq \delta 2 \neq \delta 3 \neq \delta 4 \neq 0$ i.e there is cointegration or long run relationship between the variables.

In the second step, once cointegration between the variables has been established, the long run coefficients and the error correction term (ECT) can be estimated. The ARDL cointegration procedure allows cointegrating relationship to be estimated by OLS once the lag order is selected. The model can be specified as follows:

$$
\begin{gathered}
\Delta G D P_{t}=\beta_{0}+\sum_{j=1}^{p} \beta_{1 j} \Delta G D P_{t-j}+\sum_{j=0}^{p} \beta_{2 j} \Delta D E M_{t-j}+\sum_{j=0}^{p} \beta_{3 j} \Delta P O L_{t-j}+ \\
\alpha_{1} G D P_{t-1}+\alpha_{2} D E M_{t-1}+\alpha_{3} P O L_{t-1}+\varepsilon_{1 t} \\
\Delta D E M_{t}=\beta_{0}+\sum_{j=0}^{p} \beta_{1 j} \Delta G D P_{t-j}+\sum_{j=1}^{p} \beta_{2 j} \Delta D E M_{t-j}+\sum_{j=0}^{p} \beta_{3 j} \Delta P O L_{t-j}+ \\
\alpha_{1} G D P_{t-1}+\alpha_{2} D E M_{t-1}+\alpha_{3} P O L_{t-1}+\varepsilon_{2 t} \\
\Delta P O L_{t}=\beta_{0}+\sum_{j=0}^{p} \beta_{1 j} \Delta G D P_{t-j}+\sum_{j=0}^{p} \beta_{2 j} \Delta D E M_{t-j}+\sum_{j=1}^{p} \beta_{3 j} \Delta P O L_{t-j}+ \\
\alpha_{1} G D P_{t-1}+\alpha_{2} D E M_{t-1}+\alpha_{3} P O L_{t-1}+\varepsilon_{3 t}
\end{gathered}
$$


Where $\Delta$ is the first difference operator. The residuals $\varepsilon_{i t}$ are assumed to be normally distributed and white noise.

\subsection{Granger Causality Test}

The causal relationship between the three variables is investigated through the granger causality framework. According to the concept of Granger causality, ' $\mathrm{X}$ causes $\mathrm{Y}$ ' if and only if the past values of $\mathrm{X}$ help to predict the changes of $\mathrm{Y}$. In the same way, ' $\mathrm{Y}$ causes $\mathrm{X}$ ' if and only if the past values of $Y$ help to predict the changes of X. Indeed, if a set of variables are cointegrated, there must be short run and long run causality but it cannot be captured by the standard first difference VAR model (Granger, 1969). In this case, we implement the Granger causality test with the vector error correction model (VECM) framework as follows:

$$
\begin{aligned}
& \Delta G D P_{t}=\beta_{0}+\sum_{j=1}^{p} \beta_{1 j} \Delta G D P_{t-j}+\sum_{j=0}^{p} \beta_{2 j} \Delta D E M_{t-j}+\sum_{j=0}^{p} \beta_{3 j} \Delta P O L_{t-j}+\lambda_{1} E C T_{t-1} \\
& +\mu_{1 t} \\
& \Delta D E M_{t}=\beta_{0}+\sum_{j=0}^{p} \beta_{1 j} \Delta G D P_{t-j}+\sum_{j=1}^{p} \beta_{2 j} \Delta D E M_{t-j}+\sum_{j=0}^{p} \beta_{3 j} \Delta P O L_{t-j}+\lambda_{2} E C T_{t-1} \\
& +\mu_{2 t}
\end{aligned}
$$

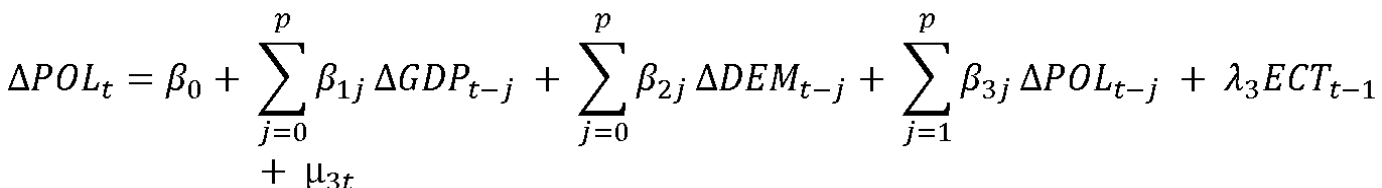

The long-run causality is indicated by negatively significant coefficients for the lagged errorcorrection term $\left(\mathrm{ECT}_{\mathrm{t}-1}\right)$ while the short-run causality is examined on the basis of likelihood ratio (LR) statistics for testing the joint significance of the lagged dynamic terms.

\section{Result and Discussion}

The unit root test provides guidance to ascertain whether ARDL is applicable or not because it is only applicable to the analysis of variables that are integrated of order zero [I(0)] or order one [I(1)], but not applicable when higher order of integration such as $\mathrm{I}(2)$ variable is involved. Testing the stationarity of the variables is important to avoid spurious regression. Thus, the Augmented Dickey-Fuller (ADF) of Dickey \& A Fuller (1981)and Phillips-Perron (PP) test by Phillips \& Perron (1986) technique were used to investigate the stationarity of the variables. The ADF and PP test results are showed in Table 3. 
Table 1. Results of the ADF and PP test

\begin{tabular}{ccccc}
\hline \multicolumn{5}{c}{ Level } \\
\hline ADF Test & \multicolumn{2}{c}{ PP Test } \\
\hline GDP & -0.182441 & 0.9248 & 0.926673 & 0.9938 \\
DEM & -3.191977 & $0.0410^{* *}$ & -5.926632 & $0.0003^{* * *}$ \\
POL & -2.394116 & 0.1603 & -0.720779 & 0.8122 \\
\hline \multicolumn{5}{c}{$\mathbf{1}^{\text {st }}$ Difference } \\
GDP & -14.64055 & $0.0000^{* * *}$ & -3.581383 & $0.0161^{* *}$ \\
DEM & -5.441639 & $0.0008^{* * *}$ & -5.536277 & $0.0007^{* * *}$ \\
POL & -5.856911 & $0.0004^{* * *}$ & -5.844424 & $0.0004^{* * *}$ \\
\hline
\end{tabular}

$* * *$ Significance at $1 \%$ level, $* *$ Significance at $5 \%$ level,$*$ Significance at $10 \%$ level.

\# MacKinnon (1996) one-sided p values.

Source :Auhtor's Calculation

Table 2. Results of The Johansen-Juselius Rank Test for Cointegration

\begin{tabular}{|c|c|c|c|c|}
\hline Hypothesized No. of CE(s) & Eigenvalue & $\begin{array}{l}\text { Trace } \\
\text { Statistic }\end{array}$ & $\begin{array}{c}\text { Critical Value } \\
10 \%\end{array}$ & Prob.** \\
\hline \multicolumn{5}{|c|}{ Bivariate cointegration rank test on GDP and Democracy } \\
\hline None & 0.277681 & 4.851649 & 13.42878 & 0.8244 \\
\hline At most 1 & 0.046785 & 0.622891 & 2.705545 & 0.4300 \\
\hline \multicolumn{5}{|c|}{ Multivariate cointegration rank test on GDP, Democracy and Political Stability } \\
\hline None & 0.689057 & 28.98485 & 27.06695 & $0.0618^{*}$ \\
\hline At most 1 & 0.649586 & 13.79895 & 13.42878 & $0.0886^{*}$ \\
\hline At most 2 & 0.012736 & 0.166634 & 2.705545 & 0.6831 \\
\hline \multicolumn{5}{|c|}{ Trace test indicates no cointegration at the 0.1 level } \\
\hline \multicolumn{5}{|c|}{ * denotes rejection of the hypothesis at the 0.1 level } \\
\hline \multicolumn{5}{|c|}{ **MacKinnon-Haug-Michelis p-values } \\
\hline
\end{tabular}

Source :Auhtor's Calculation

The null hypothesis of the unit root problem is rejected at the first difference. This shows that most variables are found to be stationary at $1^{\text {st }}$ difference implying that variables are integrated at I (1) and the variables used in this study are not all integrated of the same order, hence this study may employ the ARDL approach to test for cointegration.

After having confirmed the stationarity of the variables, the next step of the analysis was to test for cointegration among the variables. Firstly, cointegration is investigated using a multivariate approach Johansen and Juselius (1990). The results are reported in Table 2 followed by their interpretation.
This observe from the bivariate cointegration rank test that the null hypothesis cannot be rejected as the trace statistic (4.85) is less than the critical values at $10 \%$ probability levels. This study therefore conclude that democracy and economic growth are notcointegrated, that is they donot move together in the long run. This fundamental resultreveals for Indonesia that a democratic system alone doesnot ensure positiveeconomic growth. Thus,the political system alone like democracy cannot determine the country's economicperformance.

The study move to a multivariate cointegration rank test with the control variable POL, which represent political stability 
and absence of violence/terrorism. When controlledby the political stability variable, the result shows thatthe null hypothesis of a unique cointegrating relation can be rejected. From theseabove results, we can conclude that for economic growth and democracy to movetogether in the long run, they need to be associated with political stability. Although,democracy alone does not move together with economic growth in the long run, it doesso when one considers political stability as a third variable in the analysis.

Secondly, the study cross-checks the cointegration test by using the ARDL approach. ARDL bounds testing approach is employed to test for the existence of long run relationship. However, in order to do this, it is important to identify an appropriate lag length to calculate the F-statistics. The ARDL model is sensitive to the lag order. In addition, optimum lag order would be helpful in reliable and consistent result in the analysis. Thus, the Akaike Information Criterion (AIC) is considered to obtain the optimum lag length. The choice of this criterion is based on the stricter penalties imposed by AIC. This AIC provides better and consistent results compared to other lag length criteria (Uddin, Shahbaz, Arouri, \& Teulon, 2014). Based on the lag selection criteria test, the AIC maximum lag length of 1 was selected and employed in the estimation of ARDL model $(1,0,0)$.

The results are reported in Table 4. They confirm that the null hypothesis of nocointegration can be rejected at the $1 \%$ significance level when DEM serves asthe dependent variable. For this equation, the calculated $F$-statistic is greater than theupper critical values tabulated by (Pesaran et al., 2001).

Table 3. Model Selection Criteria

\begin{tabular}{ccccccc}
\hline Model & LogL & AIC* & BIC & HQ & Adj. R-sq & Specification \\
\hline \multirow{2}{*}{1} & 9.441543 & -0.777363 & -0.594775 & -0.794265 & 0.708431 & ARDL $(1,0,0)$ \\
\hline
\end{tabular}

Source :Auhtor's Calculation

Table 4. Bounds Test Results

\begin{tabular}{|c|c|c|c|c|c|}
\hline \multicolumn{3}{|c|}{$\begin{array}{c}\text { Model 1 } \\
\text { Dependent Variable }: \text { DEM } \\
\text { DEM }=f(\text { GDP,POL })\end{array}$} & \multicolumn{3}{|c|}{$\begin{array}{c}\text { Model } 2 \\
\text { Dependent Variable : GDP } \\
\text { GDP }=f(\mathrm{DEM}, \mathrm{POL})\end{array}$} \\
\hline \multirow{2}{*}{$\begin{array}{c}\text { F-statistic } \\
\text { Test }\end{array}$} & Value & $\mathrm{k}$ & F-statistic & Value & $\mathrm{k}$ \\
\hline & $6.48196^{* * *}$ & 2 & Test & 2.95177 & 2 \\
\hline \multicolumn{3}{|c|}{ Critical Value Bounds } & \multicolumn{3}{|c|}{ Critical Value Bounds } \\
\hline Significance & I0 Bound & I1 Bound & Significance & I0 Bound & I1 Bound \\
\hline $10 \%$ & 3.17 & 4.14 & $10 \%$ & 3.17 & 4.14 \\
\hline $5 \%$ & 3.79 & 4.85 & $5 \%$ & 3.79 & 4.85 \\
\hline $1 \%$ & 5.15 & 6.36 & $1 \%$ & 5.15 & 6.36 \\
\hline \multicolumn{3}{|c|}{ Conclusion :Cointegration } & \multicolumn{3}{|c|}{ Conclusion :No Cointegration } \\
\hline
\end{tabular}


In developing countries like Indonesia, political stability is a necessary conditionto undertake long-run investments such as education, health and infrastructure, which supporteconomic and social development. With five-year terms that prevail in most ofdeveloping countries, the party in power is often not confronted with sufficientincentives to promote long-term investments, although they are necessary for asustainable economic growth. The party in power prefers short run investments as theycan bring result very quick to support their reelection.

Since a long-run relationship exists between the series (Model 1), the study provides estimates ofthe long-run coefficients using a nonlinear specification. The study does so since the effect ofgrowth on democracy is not necessarily constant for every level of income. Moral-Benito \& Bartolucci (2011) for example, argue that "countries that are not fully democratic,may have good economic performances, but once they have good economic results, they hardly change their institutions". In addition, while A. Acemoglu(2008)foundthat there is no evidence of a linear effect of income on democracy, some authors like Benhabib et al. (2011), Moral-Benito \& Bartolucci (2011), Treisman (2011), and more recentlyMasaki \& Walle (2014) found evidence of a positive effect from income to democracyusing a non-linear specification. The economic and political context in Indonesia,furthermore, seems appropriate to use a non-linear specification to investigate therelationship between growth and democracy. In this way, asthe results indicate one cointegrating relation (see Table 4), the study estimate the equation where the nullhypothesis of no cointegration is rejected. The study run three different models using Ordinary Least Squares (OLS), Fully Modified Ordinary Least Squares (FM-OLS) and Dynamic Ordinary Least Squares (DOLS). The two last methods, respectively, are used to provide robust results in small sample sizes and they account the endogeneity, autocorrelation and heteroscedasticity problems. The results are reported in the Table 5 .

As can be seen, all variables are highly significant at the $1 \%$ and $5 \%$ level and have the expected signs. All the three approaches provide relatively similar results demonstrating the robustness of the results.

The results show that the non-linearity in the GDP variable reveals the existence of a minimum level of GDP required to ensure the transition to democracy as found earlier by MoralBenito \& Bartolucci(2011). Indeed, at a low level, a GDP has a negative effect on democracy. But at a given threshold, any increase in this variable positively affects democracy. The results indicate that political stability associated with economic growth will result in democracy. This is in line with the Lipset hypothesis (ormodernization theory) stating that prosperity stimulates democracy (Narayan et al., 2011).

Table 5. Cointegration Estimation (Long Run)

\begin{tabular}{ccccccc}
\hline \multirow{2}{*}{ Variable } & \multicolumn{2}{c}{$\begin{array}{c}\text { Ordinary Least Squares } \\
\text { (FM-OLS) }\end{array}$} & $\begin{array}{c}\text { Fully Modified } \\
\text { Ordinary Least Squares } \\
\text { (FM-OLS) }\end{array}$ & $\begin{array}{c}\text { Dynamic Least Squares } \\
\text { (DOLS) }\end{array}$ \\
\cline { 2 - 7 } & Coefficient & Prob. & Coefficient & Prob. & Coefficient & Prob. \\
\hline GDP & -0.034808 & $0.0205^{* *}$ & -0.041437 & $0.0006^{* * *}$ & -0.034808 & $0.0128^{* *}$ \\
POL & 0.528233 & $0.0000^{* * *}$ & 0.467938 & $0.0000^{* * *}$ & 0.528233 & $0.0000^{* * *}$ \\
\hline
\end{tabular}

** Significance at $5 \%$ level; *** Significance at $1 \%$ level

Source :Auhtor's Calculation 
Table 6. Granger Causality Results from ECM Framework

\begin{tabular}{ccccc}
\hline \multirow{2}{*}{$\begin{array}{c}\text { Dependent } \\
\text { Variable }\end{array}$} & \multicolumn{4}{c}{ Source of Causation } \\
\cline { 2 - 4 } & GDP & DEM & POL & $\begin{array}{c}\text { Long Run } \\
\text { (form ECT }\end{array}$ ) \\
\cline { 2 - 4 } & & & $-0.0878[0.7112]$ & $-0.6935[0.0432]^{* *}$ \\
\hline [significance] & & - & $0.0042[0.6056]$ & $0.0183[0.1403]$ \\
DEM & $2.4751[0.7914]$ & - & $0.0029[0.7914]$ & $0.3827[0.4540]$ \\
GDP & $-5.5500[0.6056]$ & $-0.1629[0.7112]$ & - & 0.30 \\
POL & & &
\end{tabular}

Source :Auhtor's Calculation

In adeveloping country like Indonesia, this channel can only work if some long-runeffective investments are made. Economic development is aprocess for which huge investments in personnel and material are required. Theseinclude basic public education, health, and physical infrastructure (roads, electricity,water, etc.). Still, these investments cannot be provided unless the nature of politics andgovernance in most of province changes. Such measures may not be adopted in ademocratic developing country where the system requires their submission to a popularvote of the citizens who are already living with low income levels. In this point of view, there is a kind of incompatibility between democracy and investments since increasingdemand for current consumption threatens profits and reduces investments as politicalparties are giving higher priority to the interest of the voters (Keefer, 2007). In this way, the more democratic a government is, the greater thediversion of resources from investment to consumption. Thus, political parties are lesslikely to win a clean democratic election in a poor country on a platform of currentsacrifices for a future. Based on that mechanism and the short length of terms (five-yearterms), the ruling party will forgo longrun investments by privileging the ones that arenot development-oriented (especially current consumption) to ensure their reelection. Inthis perspective, illicit tactics are often used and negatively affect the incentives ofgovernments to deliver good economic performance (Collier \& Hoeffler, 2013).

The existence of cointegrating relationship among democracy, economic growth, and political stability suggests that there must be Granger Causality in at least one direction, but it is does not indicate the direction of causality. The results of the tests for the short-run and long-run causality within ECM framework are reported in Table 6.

Beginning with the results in short-run, there is neutrality between democracy and growth, democracy and political stability, growth and political stability. In the long-run, there is a causality running from GDP and political stability to democracy as the estimated coefficient of the lagged error-correction term is negative and statistically significant in the democracy equation. This is quite a fundamental result since it tells us clearly that it is the economic performance that influences democracy and not the reverse.

\section{Conclusion}

Democracy has been postulated to be the pre-condition for economic growth. That is the argument behind the democratization process imposed by international organizations in most of the developing countries in general and in Indonesia in particular. In contrary to that, some countries like China experienced economic development although they are non-democratic. In this context, the objective of this paper was 
to investigate the causal relationship between economic growth and democracy in Indonesia. To this end, we implemented both Johansen and Juselius as well as ARDL models to cointegration to investigate the existence of a long run relation among the series. Then, Granger causality within a VECM is used to test the direction of causality between the variables in short-run and long-run. Firstly, the results show that there is cointegration among the variables specified in the model of democracy equation when political stability is taken into account. Indeed, for economic growth and democracy to move together in the long run, they need to be associated with political stability. The longrun relationship between economic growth and democracy is nonlinear revealing the existence of a minimum level of GDP required to positively impact democracy. But, economic growth can only occur in a particular environment that provides accountability, transparency, rule of law, and ethnic inclusiveness. Although such institutional change is not easy to achieve, it will bring a kind of legitimacy necessary for political stability and state building. Secondly, the tests for Granger causality conducted show that there is a long-run causality running from GDP and political stability to democracy. In other word, the economic growth and political stability Granger cause democracy. It is the economic performance that influences democracy and not the reverse. In short-run, there is neutrality causation between democracy and growth, democracy and political stability, growth and political stability.Thus, past information on a country's economic performance does permit a better prediction of the level of democratization in that country when political stability is taken into account. This reinforces the findings of a long-run relationship among the variables. The results suggest that poor countries should first of all eliminate poverty before discussing about political freedom (or election). In other words, economic growth through strong institutions is a precondition for democratization (liberal democracy). This result is consistent with Barro (1999)who states that "democracies that arise without prior economic development, sometimes because they are imposed by former colonial powers or international organizations, tend not to last". In this way, the benevolent dictator can design economic policies that favor long run investments that have high growth potential without being challenged by any political party. Thus, development partners should put emphasis on economic growth and good governance rather than just democratization. Good governance is not reduced to five-year presidential terms (or elections) but it should be viewed as a constant attempt to capture all of the considerations involved in assuring that stakeholder interests are addressed and reflected in policy initiatives. This requires careful and creative institutional design, to give political leaders and groups the incentives to behave in ways that will enhance lawfulness, stability, and trust. Such a sociopolitical environment may explain why several countries enjoy positive economic growth although they are not democratic.

\section{References}

Acemoglu, A. (2008). Income and Democracy. American Economic Review, 98(3), 808842.

Acemoglu, D., Naidu, S., Restrepo, P., \& Robinson, J. A. (2014). Democracy Does Cause Growth. SSRN. https://doi.org/10.2139/ ssrn. 2411791 .

Azman-Saini, W. N. W., Baharumshah, A. Z., \& Law, S. H. (2010). Foreign direct investment, economic freedom and economic growth: International evidence. Economic Modelling, 27(5), 1079-1089. https://doi. org/10.1016/j.econmod.2010.04.001.

Barro, R. (1999). The Determinants of Democracy. Journal of Political Economy, 107(6), 158183.

Benhabib, J., Corvalan, A., \& Spiegel, M. (2011). Reestablishing the Income-Democracy Nexus. In NBER Working Paper Series. https://doi.org/10.24148/wp2011-09. 
Jurnal Ekonomi Pembangunan: Kajian Masalah Ekonomi dan Pembangunan, 20 (2), 2019, 208-221

Benhabib, J., Corvalan, A., \& Spiegel, M. (2013). Income and democracy: Evidence from nonlinear estimations. Economics Letters (Vol. 118). https://doi.org/10.1016/j. econlet.2012.12.015.

Clague, C., Keefer, P., Knack, S., \& Olson, M. (1996). Property and Contract Rights in Autocracies and Democracies. In Journal of Economic Growth (Vol. 1). https://doi. org/10.1007/BF00138864.

Collier, P., \& Hoeffler, A. (2013). Do Elections Matter for Economic Performance? In Oxford Bulletin of Economics and Statistics (Vol. 77). https://doi.org/10.1111/ obes. 12054 .

Comeau, L. (2003). Democracy and Growth: A Relationship Revisited. Eastern Economic Journal (Vol. 29).

Cuciniello, V.(2009). The impact of fiscal-monetary policy interactions on government size and macroeconomic performance. Economic Modelling, 26(5), 918-925. https://doi. org/10.1016/j.econmod.2009.02.014.

Dickey, D., \& A Fuller, W. (1981). The Likelihood Ratio Statistics For Autoregressive Time Series With a Unit Root. Econometrica (Vol. 49). https://doi.org/10.2307/1912517.

Esposto, A., \& Zaleski, P. (1999). Economic Freedom and the Quality of Life: An Empirical Analysis. Constitutional Political Economy (Vol. 10). https://doi. org/10.1023/A:1009068829135.

Granger, C. W. J. (1969). Investigating Causal Relations by Econometric Models and Crossspectral Methods. Econometrica, 37(3), 424-438. https://doi.org/10.2307/1912791.

Haan, J., \& Sturm, J.-E. (2003). Does More Democracy Lead to Greater Economic Freedom? New Evidence for Developing Countries. European Journal of Political Economy (Vol. 19). https://doi.org/10.1016/ S0176-2680(03)00013-2.

Zouhaier, H., \& KEFI, M. K. (2012). Interaction between political instability and investment. Journal of Economics and International Finance, 4(2), 49-54.

Heid, B., Working, I., No, P., \& Langer, J. (2011). GMM7. (118).

Johansen, S., \& Juselius, K. (1990). Maximum Likelihood Estimation and Inference on Cointegration--With Applications to the Demand for Money. Oxford Bulletin of Economics and Statistics, 52(2), 169-210. Retrieved from https://econpapers.repec. org/RePEc:bla:obuest:v:52:y:1990:i:2 :p:169-210.

Keefer, P. (2007). Clientelism, Credibility, and the Policy Choices of Young Democracies. American Journal of Political Science (Vol. 51). https://doi.org/10.1111 /j.1540-5907.2007.00282.

Masaki, T., \& Walle, N. van de. (2014). The Impact of Democracy on Economic Growth in SubSaharan Africa, 1982-2012. Helsinki, Finland: UNU-WIDER.

Moral-Benito, E., \& Bartolucci, C. (2011). Income and Democracy: Revisiting the Evidence. Economics Letters (Vol. 117). https://doi. org/10.2139/ssrn.1883428.

Narayan, P. K., Narayan, S., \& Smyth, R. (2011). Does democracy facilitate economic growth or does economic growth facilitate democracy? An empirical study of SubSaharan Africa. Economic Modelling, 28(3), 900-910. https://doi.org/10.1016/j. econmod.2010.11.004.

Pesaran, H., J. Smith, R., \& Shin, Y. (2001). Bound Testing Approaches to the Analysis of Level Relationship. Journal of Applied Econometrics (Vol. 16). https://doi. org/10.1002/jae.616.

Phillips, P., \& Perron, P. (1986). Testing for a Unit Root in Time Series Regression. Cowles Foundation, Yale University, Cowles Foundation Discussion Papers (Vol. 75). https://doi.org/10.1093/biomet/75.2.335. 
Rachdi, H., \& Saidi, H. (2015). Democracy and Economic Growth: Evidence in MENA Countries. Procedia - Social and Behavioral Sciences, 191, 616-621. https:// doi.org/10.1016/j.sbspro.2015.04.644.

Rodrik, D. (1998). Where Did All The Growth Go? External Shocks, Social Conflict, and Growth Collapses. National Bureau of Economic Research Working Paper Series, No. 6350. https://doi.org/10.3386/w6350.

Treisman, D. (2011). Income, Democracy, and the Cunning of Reason.

Uddin, G., Shahbaz, M., Arouri, M., \& Teulon, F. (2014). Financial development and poverty reduction nexus: A cointegration and causality analysis in Bangladesh. Economic Modelling (Vol. 36). https://doi. org/10.1016/j.econmod.2013.09.049.

Ur Rehman, I., \& Shahbaz, M. (2014). Multivariate-based Granger causality between financial deepening and poverty: the case of Pakistan. Quality \& Quantity (Vol. 48). https://doi.org/10.1007/s11135013-9952-z. 
Avalaible online at http://journals.ums.ac.id, Permalink/DOI: 10.23917/jep.v20i2.7581

Jurnal Ekonomi Pembangunan: Kajian Masalah Ekonomi dan Pembangunan, 20 (2), 2019, 208-221

\section{Appendix}

Table A1.Descriptive Statistics of Sample Data

\begin{tabular}{cccccc}
\hline \multicolumn{5}{c}{ Descriptive Statistics } \\
\hline Variables & $\mathbf{N}$ & Minimum & Maximum & Mean & $\begin{array}{c}\text { Std. } \\
\text { Deviation }\end{array}$ \\
\hline GDP & 22 & 2071.55 & 3974.06 & 2776.9993 & 609.72325 \\
DEM & 19 & .19 & .60 & .4446 & .13253 \\
POL & 23 & -2.09 & -0.37 & -1.10737 & 0.569013 \\
\hline
\end{tabular}

Source : EIU, The Global Economy and World Bank 